\title{
Socio-Institutional Drivers of Groundwater Contamination Hazards: The Case of On-Site Sanitation in the Bwaise Informal Settlement, Kampala, Uganda
}

Felix R. B. Twinomucunguzi ${ }^{1,2}, * \mathbb{C}$, Giorgia Silvestri ${ }^{3}$, Joel Kinobe ${ }^{1}$, Allan Mugabi ${ }^{2}$, Jenifer Isoke ${ }^{4}$, Philip M. Nyenje ${ }^{1}$, Jan Willem Foppen ${ }^{5}$, Robinah N. Kulabako ${ }^{1}$ and Frank Kansiime ${ }^{6}$

1 Department of Civil and Environmental Engineering, College of Engineering, Design, Art and Technology, Makerere University, Kampala P.O. Box 7062, Uganda; kinobejoe@gmail.com (J.K.); nyenje@gmail.com (P.M.N.); rkulaba@gmail.com (R.N.K.)

2 Department of Urban Water and Sewerage Services, Ministry of Water and Environment, Kampala P.O. Box 20026, Uganda; allan.mugabi@gmail.com

3 DRIFT (Dutch Research Institute for Transitions), Erasmus University Rotterdam, P.O. Box 1738, 3000 DR Rotterdam, The Netherlands; silvestri@drift.eur.nl

4 Department of Engineering and Environment, Faculty of Science and Technology, Uganda Christian University, Mukono P.O. Box 4, Uganda; jenniferisoke@yahoo.co.uk

5 Department of Water Science and Engineering, IHE Delft Institute for Water Education, P.O. Box 3015, 2601 DA Delft, The Netherlands; j.foppen@un-ihe.org

check for updates

Citation: Twinomucunguzi, F.R.B.; Silvestri, G.; Kinobe, J.; Mugabi, A.; Isoke, J.; Nyenje, P.M.; Foppen, J.W.; Kulabako, R.N.; Kansiime, F. Socio-Institutional Drivers of Groundwater Contamination Hazards: The Case of On-Site Sanitation in the Bwaise Informal Settlement, Kampala, Uganda. Water 2021, 13, 2153. https://doi.org/ $10.3390 / w 13162153$

Academic Editors: Viviana Re and Theresa Frommen

Received: 31 May 2021

Accepted: 2 August 2021

Published: 5 August 2021

Publisher's Note: MDPI stays neutral with regard to jurisdictional claims in published maps and institutional affiliations.

Copyright: (C) 2021 by the authors Licensee MDPI, Basel, Switzerland. This article is an open access article distributed under the terms and conditions of the Creative Commons Attribution (CC BY) license (https:// creativecommons.org/licenses/by/ $4.0 /)$.
6 Department of Environmental Management, Makerere University, Kampala P.O. Box 7062, Uganda; fkansiime@gmail.com

* Correspondence: twinof@gmail.com; Tel.: +256-772-588-651

Abstract: Socio-institutional factors are poorly addressed in the risk assessment of groundwater contamination. This paper contributes to the development of a socio-institutional assessment framework based on a case study of contamination by on-site sanitation (OSS) in an informal settlement of Bwaise (Kampala, Uganda). We conducted a snapshot survey of the recent extent of groundwater contamination by OSS using microbial and hydro-chemical indicators. Through transition arenas and key informant interviews, we investigated the socio-institutional drivers of the contamination. Overall, 14 out of the 17 sampled groundwater sources tested positive for Escherichia coli during the wet season. Nitrate concentrations at four sources exceeded the World Health Organization guideline value (50 mg/L), attributed to OSS. Despite the high contamination, the community highly valued groundwater as an alternative to the intermittent municipal water supply. We deduced six drivers of groundwater contamination, including land-use management, user attributes, governance, infrastructure management, groundwater valuation, and the operating environment ("LUGIVE"). Qualitative indicators for each of the drivers were also construed, and their interlinkages presented in a causal loop diagram, representing a socio-institutional assessment framework. The framework can help policymakers and the community to analyze various socio-institutional control levers to reduce the risk of groundwater contamination by OSS in informal settlements.

Keywords: contamination; groundwater; informal settlements; on-site sanitation; socio-hydrogeological systems

\section{Introduction}

Groundwater is essential for sustaining ecosystem services. However, globally, over 1.7 billion people depend upon groundwater resources threatened by increasing contamination and depletion [1]. Groundwater contamination hazards include microbial, chemical, and, more recently, micropollutants of emerging concern [2-4]. Microbial pathogen contamination, including bacteria, viruses, protozoa, and helminths, have been most prevalently reported, especially in the developing world where inadequate sanitary practices prevail $[3,5]$. The increasing risk of groundwater contamination is a significant hindrance 
to meeting the sustainable development goal (SDG) number 6, to ensure availability and sustainable management of water and sanitation for all [6].

On-site sanitation (OSS) practices are significant and persistent sources of groundwater contamination hazards in Sub-Saharan Africa (SSA) [2,3,5]. OSS refers to sanitation (fecal) disposal systems that are not connected to a sewerage network, including pit latrines and septic tanks [2,3]. In SSA, over $70 \%$ of the population relies upon groundwater for domestic use, in a situation where the majority of the residents use unimproved sanitation facilities for disposal of fecal waste, mainly OSS [7-9]. Urban communities living in informal settlements in SSA are at high risk to the effects of groundwater contamination from OSS, considering the low level of municipal water supply in these areas [8-11]. Several disease outbreaks with fatalities have been reported in communities living in informal settlements, attributed to the high risk of groundwater contamination by OSS $[3,5,8]$. Therefore, there is a need to improve groundwater contamination risk management in informal settlements, which are home to over $30 \%$ of the urban population in developing countries [12]. The challenge continues to grow with increasing populations and urbanization, which calls for continuous groundwater contamination risk assessment to devise strategies to mitigate the hazards.

Groundwater contamination risk assessment refers to a process of identifying hazards, analyzing the risks associated with the hazard, and determining strategies to control the risk [13]. It encompasses both intrinsic vulnerability assessment and hazard assessment [14]. Intrinsic vulnerability represents the groundwater sensitivity to possible contamination, mainly governed by hydrogeological characteristics of an area, which are rather static. Intrinsic vulnerability assessment has been extensively studied, including process-based methods (using numerical modeling software such as MODFLOW (The US Geological Survey, Reston, VA, USA), HYDRUS (PC-Progress, Prague, Czech Republic), and MIKE SHE (DHI A/S, Hørsholm, Denmark)), statistical methods (such as Genetic Algorithms, Artificial Neural Networks, and Fuzzy-Logic) and overlay/index methods (including DRASTIC, GOD, and SINTACS) [14-21]. A description of the acronyms is provided in Appendix A. On the other hand, hazard analysis interrogates the pollutant characteristics and possible sources of contamination, representing rather dynamic parameters [16-18]. "Land-use characteristics" has been used as a proxy indicator for analyzing anthropogenic influences in hazard assessment, usually emphasizing the level of urban sanitation infrastructure as the primary driver of sanitation-related hazards $[17,19,20]$. However, socio-institutional dynamics, including socio-economic aspects, political, policy, socio-cultural, and institutional arrangements, greatly influence the level and effective utilization of sanitation infrastructure, which have not been adequately included in groundwater contamination risk assessment. Insufficient analysis of the socio-institutional dynamics limits the scope of management strategies towards addressing the contamination risk. There is, thus, a need for an improved socio-institutional assessment framework to augment the predominantly hydrogeological vulnerability assessment tools in groundwater contamination risk assessment.

Integrated socio-hydrogeological analysis of groundwater problems has been gaining attention in recent studies considering the increasing awareness of the complexity in water resource management as part of a broader domain of socio-hydrology [22-24]. Tringali et al. [23] explored the key stakeholders in groundwater management, while Re et al. [22] also applied public participation in identifying the principal sources of nitrate contamination in the Grombalia basin (Tunisia). Integrated multi-disciplinary tools for assessing contamination risks are the foundation for implementing water safety plans (WSP) for preventing contamination risks to public water supplies $[25,26]$. However, the implementation of WSPs in small community water supply systems in low- and middle-income countries has been low due to limited appropriate multi-disciplinary tools, among other reasons [26]. Multi-disciplinary approaches have also been explored in the implementation of integrated water resources management (IWRM), although with limited attention to groundwater [27-29]. Integrative approaches have also been advanced in the past two 
decades in the realm of sustainability transitions in addressing complex and persistent societal problems [29-31]. The concept of "socio-technical systems" has emerged in transition studies, which analyzes an overall system including interactions between actors, technologies, and institutions in the long-term change towards sustainability [30-33]. Transition studies have been extensively explored in the urban context, although mostly in developed countries [32,34]. Thus, applying transition approaches, together with existing water resources management approaches, has been postulated to improve the understanding of socio-technical dynamics influencing groundwater contamination by OSS [33].

Therefore, this paper aims to contribute to the development of a socio-institutional assessment framework for groundwater contamination hazards from OSS practices in informal settlements in SSA using a socio-technical approach. A typical informal settlement of Bwaise (Kampala city, Uganda) was studied due to the existence of a groundwater monitoring network established by a multi-stakeholder action-research project named "T-GroUP". Microbial and hydrogeochemical studies have also been undertaken in the last decade attesting to groundwater contamination by OSS in the catchment area of Bwaise informal settlement $[3,10,11]$. Therefore, this study contributes to the development of a socio-hydrogeological risk assessment framework, which would enable the community and policymakers in identifying key action levers essential in the implementation of WSPs to mitigate the growing risk of groundwater contamination by OSS in informal settlements in SSA.

This paper is structured as follows: the analytical framework guiding the study is described in detail in Section 2, while Section 3 presents the research design and methodology. The main findings of the study are presented in Section 4, while the implications of the findings are discussed in Section 5. The main conclusions and recommendations for further research are presented in Section 6.

\section{Analytical Framework}

The WSP approach, introduced by the World Health Organization (WHO) in 2004, adopts a participatory process in identifying, assessing, and managing contamination risks to public water supply systems $[25,26]$. In SSA, this has mainly been implemented in the context of governance frameworks influenced by IWRM [28,29]. IWRM is implemented through a general framework based upon three pillars of "creating an enabling environment", "developing management instruments", and "defining institutional roles for action" towards the overarching goal of ecological, social, and economic sustainability [27]. However, significant challenges in IWRM implementation in SSA have included a limited focus on groundwater aspects and ineffective socio-institutional integration $[28,29,35,36]$. Thus, there is growing literature on integrated socio-hydrogeological studies using different theoretical groundings to address these gaps $[18,22,23]$. Sustainability transition approaches have been explored to augment the existing governance frameworks in addressing complexity challenges $[33,37,38]$. In transition studies, the multi-level perspective (MLP) is a widely applied framework used to analyze socio-technical transitions [31,38], structured along three heuristic levels of analysis: the macro level, meso level, and micro level. The macro level is described as the "socio-technical landscape" that constitutes the external environment. The meso level represents the "socio-technical regime" encompassing the "rule-set" that governs the system of analysis [38]. The micro level includes "niches", which are protected spaces where innovations emerge to challenge regimes to reconfigure the socio-technical system to the desired societal goal [31].

We conceptualize a "water and sanitation services regime" that considers dynamics from water and sanitation service delivery. Water and sanitation services in informal settlements in SSA can be considered "protected spaces" in light of the low water and sanitation service levels [12,39]. Therefore, the implementation of a WSP for the protection of groundwater in order to foster the increased utilization of groundwater was explored as a specific niche influenced by the water and sanitation service regime to serve the economically vulnerable community living in informal settlements. WSPs have been mainly imple- 
mented by utilities for piped water supply systems [26]. The innovation by the community in the Bwaise informal settlement involved applying the WSP principles in protecting groundwater wells and springs, including the analysis of groundwater contamination, formation of management structures, advocating for improved and innovative sanitation infrastructure, and activities for improving sanitary conditions around water sources. The socio-institutional drivers of groundwater contamination from OSS in informal settlements can be analyzed through an understanding of the enabling environment and actor influences at the three analytical levels of "socio-technical landscape", "socio-technical regime", and "niche" level, as shown in Figure 1.

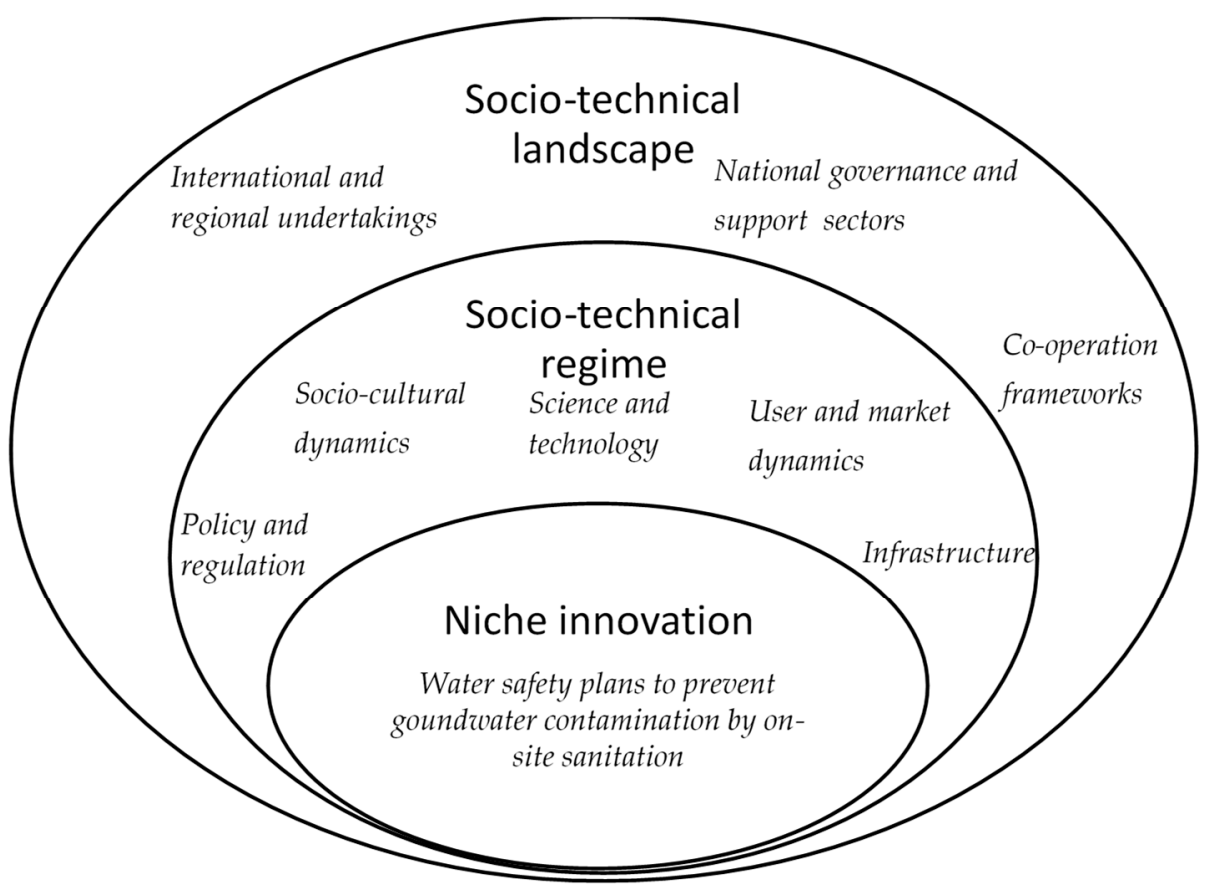

Figure 1. The analytical framework for analyzing socio-institutional drivers of on-site sanitation hazards to groundwater in the Bwaise informal settlement (Adapted from $[27,33,38]$ ).

\section{Research Design and Methodology}

A case study design was adopted to gain in-depth insight into the socio-institutional dynamics influencing groundwater contamination by OSS in informal settlements. A case study design presents strengths in understanding such real-life phenomena and their contexts [40]. A single case study can also provide a rich, empirical, and evidence-based description of a contemporary phenomenon in order to generate testable theoretical concepts [41]. The case study focused on a typical informal settlement named Bwaise in Kampala city, Uganda's capital, and its surroundings. The area was part of the study area for the "T-GroUP" project, a five-year research project (2015-2020) exploring sustainable groundwater management approaches for the benefit of the urban poor. Bwaise was selected due to the existence of a groundwater monitoring network to assess the recent extent of contamination and the existence of background studies on groundwater contamination by OSS [3,10,11]. Multiple data collection methods were used, including water quality analysis for parameters usually associated with anthropogenic groundwater contamination, key informant interviews, and transition arenas. Multiple data collection methods improve the internal validity of research $[40,41]$.

\subsection{Study Area}

The Bwaise informal settlement lies northwest of Kampala city, in the Kawempe Division, extending to parts of the Nansana Division in Wakiso District, covering an area of approximately 300 hectares (Figure 2). The settlement density is high, with approximately 
27,000 inhabitants per square kilometer [42], characterized by low-income housing, transcending into the Lubigi wetland in the low-lying areas. The area lies in a gently rolling topography, where the low-lying areas are generally underlain by alluvial deposits and clay soils overlain by fine sand and loamy topsoil. The geological formation is characterized by a deeply weathered lateritic regolith (approximately $30 \mathrm{~m}$ thick) atop Precambrian basement rocks consisting of predominantly undifferentiated granite-gneiss rocks of the Buganda-Toro formation [43]. This study focused on shallow groundwater, occurring within the weathered regolith dominated by kaolinite and quartz minerals. The lithological profile at sampled sites, obtained from drilling logs by the T-GroUP, is provided in Supplementary Material A (Figure S1). The saturated hydraulic conductivity of the shallow aquifer is estimated in the range of $0.05-2.9 \mathrm{~m} / \mathrm{d}$ [10]. The climate is generally a tropical rainforest climate, modified by the Lake Victoria Basin, with a bimodal rainfall pattern. The rainy season falls in the months of March-May and October-December [44].

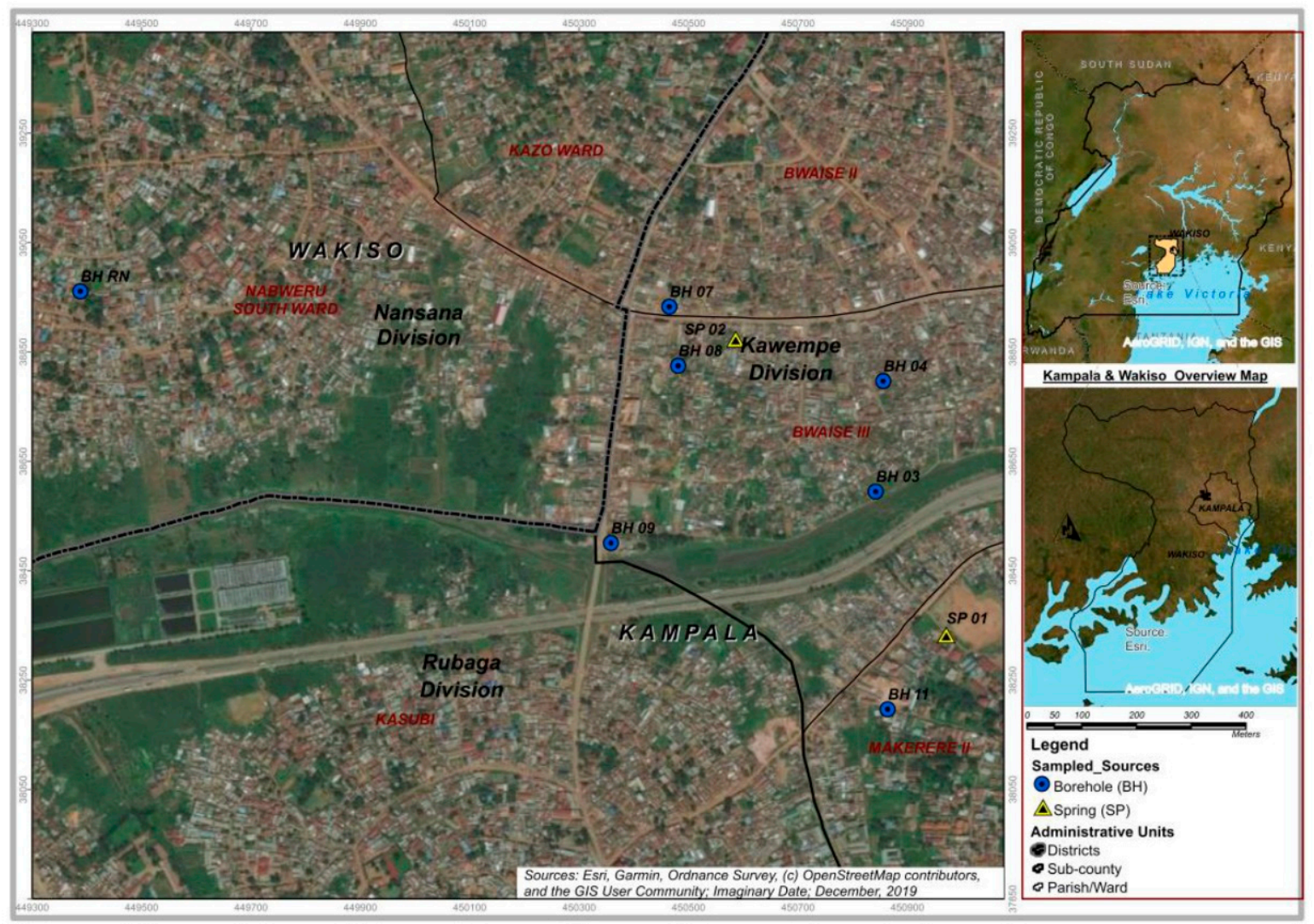

Figure 2. Location of the Bwaise informal settlement and location of the sampled sources.

The main water sources for the community include the municipal water supply, groundwater sources (springs, boreholes, and traditional wells), and, to a lesser extent, rainwater harvesting options [11,45]. The municipal water network represents the dominant infrastructure, serving approximately $80 \%$ of the population [45]. However, the service is highly unreliable, and most of the residents occasionally use groundwater as an alternative [11,45].

The majority of the residents in the Bwaise informal settlements rely on OSS facilities in the form of pit latrines and septic tanks [46]. Previous studies undertaken with the catchment of Bwaise in the last decades have revealed groundwater contamination by OSS [3,10,11]. Kulabako et al. [11] investigated the hydrogeochemical characteristics of 16 shallow groundwater sources in Bwaise over a period of 19 months, showing high contamination from OSS sources (up to $779 \mathrm{mg} / \mathrm{L}$ of nitrate, $13 \mathrm{mg} / \mathrm{L}$ of total phosphorus, and the presence of microbial elements (thermotolerant coliforms and faecal streptococci)). 
Lutterdot et al. [3] also surveyed 77 springs located within the Lubigi catchment and showed that almost all the tested sources showed elevate nitrates (up to $136 \mathrm{mg} / \mathrm{L}$ ), thermotolerant coliforms (positive in $97 \%$ of the sources), and chlorides (up to $151 \mathrm{mg} / \mathrm{L}$ ). Nyenje et al. [10] also showed high concentrations of nitrate (up to $228 \mathrm{mg} / \mathrm{L}$ ), ammonium (up to $57 \mathrm{mg} / \mathrm{L}$ ), and orthophosphate (up to $2.4 \mathrm{mg} / \mathrm{L}$ ) downgradient of pit latrines in the Bwaise area.

The municipal water supply is managed by National Water and Sewerage Corporation (NWSC), a national utility for water supply and sewerage services in major urban areas in Uganda. The Kampala Capital City Authority (KCCA) regulates the administrative functions in the city, including the public health aspects of sanitation. The central government structures (including the Ministry of Water and Environment (MWE), Ministry of Health $(\mathrm{MoH})$, and National Environmental Management Authority (NEMA)) provide technical and regulatory oversight to the water and sanitation regime in Uganda. Multilateral and bilateral development partners, civil society, and researchers are among the key actors who influence the water and sanitation dynamics in Kampala.

\subsection{Groundwater Sample Collection and Water Quality Analysis}

During the snapshot survey, a total of 17 groundwater sources located at 9 sites within the study area were sampled (Figure 2). The sources included 15 drilled observation wells (at varying depths ranging from $3 \mathrm{~m}$ to $37 \mathrm{~m}$ ) and 2 protected springs. On-site sanitary inspections were performed to assess the risk of contamination (ROC) from other sanitary conditions within the immediate surroundings of the sampled sources. The ROC scoring was in accordance with the parameters suggested by the WHO, as widely used in the literature $[47,48]$, which are presented in Supplementary Material A (Table S1). Two sampling rounds were undertaken: at the end of the dry season (March 2018) and at the end of the following wet season (December 2018). In order to ensure a representative sample, observation wells were purged by extracting a minimum of three well-casing water column volumes one day prior to the sampling day. Abstraction from the observation wells was achieved with the aid of an electric vacuum pump (12 V). The samples were collected in sterilized $100 \mathrm{~mL}$ plastic bottles and transported in a cool box $\left(\right.$ at $\left.4{ }^{\circ} \mathrm{C}\right)$ to the National Reference Laboratory, Entebbe, for analysis within four hours of sample collection. The microbial analysis included the enumeration of Escherichia coli (E. coli) using the Colilert-18 method (IDEXX Laboratories Inc.). The hydro-chemical parameters of nitrate $\left(\mathrm{NO}_{3}{ }^{-}\right)$, chloride $\left(\mathrm{Cl}^{-}\right)$, sulphate $\left(\mathrm{SO}_{4}{ }^{2-}\right)$, and ammonia $\left(\mathrm{NH}_{3}\right)$ were analyzed with the use of an automated discrete photometric analyzer (Thermo Scientific Gallery Plus). These parameters are recommended for the rapid assessment of anthropogenic groundwater contamination [47].

\subsection{The Transition Arenas and Key Informant Interviews}

Transition arenas are interactions between a network of a specific group of people (termed as "frontrunners") aiming to find sustainable solutions to a persistent, complex societal challenge [29]. The transition arenas conducted in the Bwaise informal settlement included four arena meetings composed of 17 community members, with an average 35\% female composition. The arenas were conducted between 2017 and 2020. The arenas were held under the themes of (1) problem structuring, (2) envisioning (held twice), and (3) transition agenda setting. The arena participants were selected based on their local knowledge and interest in the subject. Additionally, two stakeholder engagements with high-level institutional stakeholders-including central government, KCCA, NWSC, MWE, NEMA, research institutions, and civil society representatives-were held in July 2018 and August 2019. In order to harness a deeper understanding of the socio-institutional dynamics influencing groundwater contamination by OSS hazards in informal settlements, key informants were purposively selected for in-depth interviews, as shown in Table 1. A total of 34 semi-structured in-depth interviews were conducted, determined by reaching the data saturation point. Depending upon the nature of the study, research instruments, 
data collection methods, and homogeneity of respondents, a data saturation point is observed when additional interviews do not generate any new information or codes [49]. The interview and transition arena guides are provided in Supplementary Material B. The interviews and transition arenas were recorded (manually or digitally) and later transcribed for analysis.

Table 1. Key informant interviews conducted.

\begin{tabular}{cc}
\hline Participant Descriptors & Number of Respondents \\
\hline Bwaise community members & 2 \\
Water utility (National Water and Sewerage Corporation) & 3 \\
City authority (Kampala Capital City Authority) & 3 \\
Civil society & 5 \\
Development partners & 2 \\
Private sector (Consultants) & 3 \\
Research institutions & 2 \\
National Environmental Management Authority & 3 \\
Ministry of Water and Environment & 8 \\
Ministry of Health & 3 \\
\hline
\end{tabular}

\subsection{Data Analysis}

The water quality data were graphically presented in "Microsoft Office Excel", version 2018 (Microsoft, Seattle, WA, USA), while the correlation analysis was performed using IBM SPSS software, version 20 (International Business Machines Corporation (IBM), New York, NY, USA). The socio-institutional data were qualitatively analyzed using "ATLAS.ti", version 8.4.25 (ATLAS.ti Scientific Software Development GmbH, Berlin, Germany). Thematic analysis was adopted to analyze the data, a flexible methodology applicable to both inductive and deductive epistemology [50]. The study team carefully reviewed the data and read through the transcripts to identify preliminary codes of analysis. The data were then coded, mainly using descriptive and interpretive coding approaches. The codes were grouped into categories from which themes were generated, representing the main socio-institutional drivers of groundwater contamination by OSS in the Bwaise informal settlement. "Vensim", version PLE 8.2.0 (Ventana Systems, Inc., Harvard, MA, USA), was used to represent networks between the socio-institutional drivers through a causal loop diagram (CLD). Expert opinion and participant feedback were employed for validation of the qualitative findings as suggested in the literature [40,51]. CLDs have been widely used in the literature to represent complex socio-technical systems, including water resources management problems [52,53].

\section{Findings}

\subsection{Groundwater Contamination by On-Site Sanitation in the Bwaise Informal Settlement}

The recent extent of groundwater contamination in Bwaise was assessed through water quality analysis for $E$. coli, $\mathrm{NO}_{3}{ }^{-}, \mathrm{Cl}^{-}, \mathrm{SO}_{4}{ }^{2-}$ and $\mathrm{NH}_{3}$, which are usually associated with anthropogenic groundwater contamination from wastewater sources. The prevalence of $E$. coli contamination for each of the wells sampled during the wet and dry seasons is presented in Figure 3. During the wet season, 14 of the 17 sources showed E. coli contamination, while only 11 sources registered counts for E. coli during the dry season. The borehole BH 11 location registered the highest count in both the wet and dry seasons, while boreholes BH $08(18 \mathrm{~m}), \mathrm{BH} 04(25 \mathrm{~m})$, and spring SP 02 did not register any E. coli during either the wet or dry seasons. The risk of contamination from sanitary conditions at the source was generally intermediate/medium for most of the sources, except for $\mathrm{BH}$ 07, $\mathrm{BH} 09$, and SP 02 , which were categorized as a low level of risk. The qualitative risk assessment for each of the sources is presented in Supplementary Material A (Table S1). 


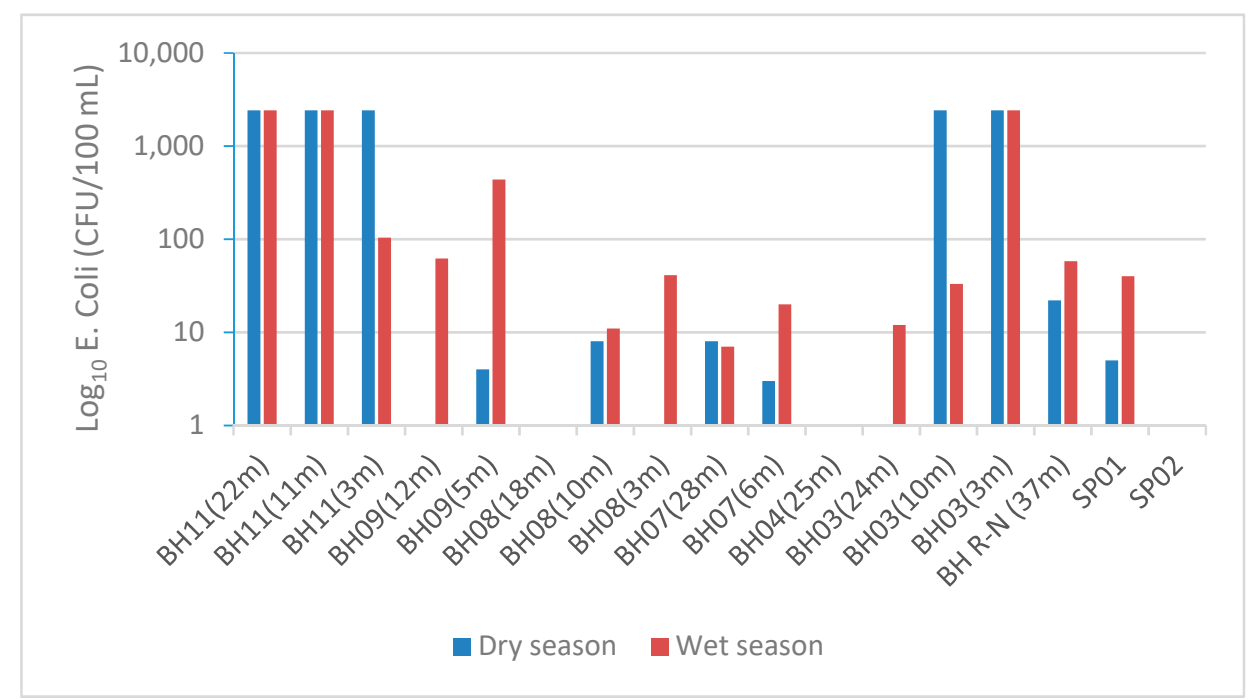

Figure 3. Prevalence of E. coli contamination in the sampled sources in the study area.

The descriptive statistics for hydro-chemical characteristics of the sampled sources are shown in Table 2. The measurements recorded for each sampled source are presented in Supplementary Material A (Table S2). The results show that the $\mathrm{NO}_{3}{ }^{-}$concentrations measured at four of the sampled groundwater sources (during both the wet and dry seasons) exceeded the WHO guideline value of $50 \mathrm{mg} / \mathrm{L}$. The $\mathrm{NH}_{3}$ concentrations at four locations during the wet season and two locations during the dry season also exceeded the Uganda standard value for potable water of $0.5 \mathrm{mg} / \mathrm{L}$. The $\mathrm{Cl}^{-}$and $\mathrm{SO}_{4}{ }^{2-}$ concentrations observed in the data were below the Uganda standard values for potable water.

Table 2. Descriptive statistics of selected hydro-chemical parameters in sampled groundwater sources from the Bwaise informal settlement (values are given in $\mathrm{mg} / \mathrm{L} ; n=17$ for both wet and dry seasons).

\begin{tabular}{|c|c|c|c|c|c|c|c|c|c|c|}
\hline \multirow{2}{*}{ Parameters } & \multicolumn{4}{|c|}{ Dry Season } & \multicolumn{4}{|c|}{ Wet Season } & \multirow{2}{*}{$\begin{array}{c}\text { WHO } \\
\text { Guidelines [54] }\end{array}$} & \multirow{2}{*}{$\begin{array}{c}\text { Uganda } \\
\text { Standards }\end{array}$} \\
\hline & Min. & Max. & Mean & Stan. Dev. & Min. & Max. & Mean & Stan. Dev. & & \\
\hline Nitrate & 1.0 & 231 & 34 & 60 & 0.1 & 208 & 35 & 59 & 50 & 45 \\
\hline Chloride & 2.3 & 87 & 22 & 21 & 2.5 & 103 & 25 & 27 & - & 250 \\
\hline Ammonia & 0.0 & 3.9 & 0.6 & 1.0 & 0.0 & 2.2 & 0.2 & 0.5 & - & 0.5 \\
\hline Sulphate & 2.1 & 20 & 8.9 & 5.1 & 2.4 & 18 & 8.2 & 4.8 & - & 400 \\
\hline
\end{tabular}

A Pearson correlation analysis of the data for both the wet and dry seasons showed a strong positive significant correlation between the $\mathrm{NO}_{3}{ }^{-}$and $\mathrm{Cl}^{-}$concentrations (for $n=34 ; r=0.908 ; p<0.01$ ). A positive correlation shows that both the $\mathrm{NO}_{3}{ }^{-}$and $\mathrm{Cl}^{-}$are possibly released from a common source. The $\mathrm{NO}_{3}{ }^{-}: \mathrm{Cl}^{-}$ratio greater than one has been reported to signal groundwater contamination by fecal matter [2]. From the study findings, the $\mathrm{NO}_{3}{ }^{-}: \mathrm{Cl}^{-}$ratio at seven of the sources during the wet season, and five sources during the dry season, ranged between 1 and 3.6, indicating possible fecal contamination.

\subsection{Socio-Institutional Drivers of Groundwater Contamination by OSS in the Bwaise Informal Settlement}

The socio-institutional drivers of groundwater contamination by OSS were deduced from the key informant interviews and transition arenas (the codes and themes analyzed are provided in Supplementary Material C, Table S3). The drivers were analyzed along the levels of the "socio-technical regime", "socio-technical landscape", and "niche" (Table 3). The qualitative indicators for the drivers were also deduced from the study findings (Table 3). 
Table 3. Socio-institutional drivers and indicators of groundwater contamination by on-site sanitation in the Bwaise informal settlement.

\begin{tabular}{|c|c|c|}
\hline Analytical Level & Socio-Institutional Drivers & Indicators \\
\hline \multirow{4}{*}{ Socio-technical regime influences } & Land-use management & $\begin{array}{c}\text { Access to land for sanitation improvement activities } \\
\text { Level of urbanization } \\
\text { Level of physical planning } \\
\text { Level of catchment protection measures }\end{array}$ \\
\hline & Infrastructure management & $\begin{array}{l}\text { Access to improved sanitation infrastructure } \\
\text { Cost of improved sanitation infrastructure } \\
\text { Access to municipal water infrastructure } \\
\text { Level of drainage infrastructure }\end{array}$ \\
\hline & User attributes & $\begin{array}{c}\text { Safe water chain practices } \\
\text { Behaviors and attitudes } \\
\text { Waste disposal practices } \\
\text { Perceptions to groundwater quality } \\
\text { Poverty levels (unemployment levels) } \\
\text { Influence of religious and cultural beliefs }\end{array}$ \\
\hline & Governance & $\begin{array}{c}\text { Groundwater management practices } \\
\text { Attention to common-pool resources } \\
\text { Level of sanitation service chain management } \\
\text { Effectiveness of policy and regulatory mechanisms } \\
\text { Level of financing } \\
\text { Political interference in enforcement } \\
\text { Actor performance and collaborations } \\
\text { Capacity at the community level } \\
\text { Weaknesses in decentralization of resources (finances) } \\
\text { Policy and regulation limitations } \\
\text { Application of science, research, and innovation } \\
\text { Competition from the municipal water supply }\end{array}$ \\
\hline Socio-technical landscape influences & Operating environment & $\begin{array}{c}\text { International and regional collaborative networks } \\
\text { Level of industrialization } \\
\text { Supportive governance } \\
\text { Natural phenomena (climate change effects) }\end{array}$ \\
\hline Niche influences & Groundwater valuation & $\begin{array}{c}\text { Groundwater utilization } \\
\text { Community awareness } \\
\text { Community support and participation }\end{array}$ \\
\hline
\end{tabular}

The socio-technical regime factors influencing groundwater contamination by OSS in the Bwaise informal settlement were most prominent (Table 3). Land-use management, including limited access to land for development activities, was assessed to be among the key factors. The results show that uncontrolled urbanization during poor physical planning affects the efforts towards implementing improved sanitation approaches. The NWSC expressed concern about the lack of space to implement projects like improved public toilets, which would contribute to the alleviation of the problem. The land tenure system in Bwaise is complicated, mostly owned by the Buganda kingdom and "absentee" landlords, thus discouraging investment in permanent structures. Most of the landlords are not residents in Bwaise; thus, they are not moved on the need to improve the sanitation situation in the area.

The study findings highlight the limited affordability by the residents to construct improved sanitation facilities at the household level and the lack of public resources to invest in sewerage networks. Infrastructure management also encompasses safe emptying/collection and transportation, treatment, and disposal/re-use. The situation is compounded by the location of the Bwaise informal settlement in a low-lying area, with a high groundwater table, where the ordinary pit latrine would be flooded. Thus, the residents rely on raised latrines, which are relatively expensive to construct. 
User attributes were also analyzed to significantly influence groundwater contamination by OSS in the study area. Urban areas attract people from different cultural backgrounds who have different beliefs and practices on water and sanitation. Participants cited examples from certain cultures such as "young children and pregnant women are not supposed to use pit latrines". Such practices promote open defecation, which leads to an increased risk of groundwater contamination.

From Table 3, the governance factors influencing groundwater contamination by OSS in informal settlements include actor collaborations, policy, and regulation, as well as financing and political influences. The findings show that the clarity of roles and coordination of the actors in the management of groundwater resources in the city, especially the state actors, remains a key challenge to service provision and contamination prevention in Bwaise. The NWSC supplies the municipal water from surface water abstraction (Lake Victoria) and, thus, does not have much support for groundwater management in the area, as one of the central government participants stated:

"The NWSC only promotes piped water but does not venture much into the groundwater ... They are looking at getting profits out of the service (water services), so they are focusing more on the revenue than protection."

The National Environment Management Authority (NEMA), which should control environmental pollution, is mainly concerned with point source contamination from industrial sources, with limited regard to the "diffuse" contamination from OSS in the highly dense settlements like Bwaise.

The political support or interference in sanitation improvement programs is also highlighted in the study findings. Sanitation improvement initiatives by the local authority are sometimes challenged by "vote-seeking" politicians, advocating for free-of-charge services, which are not sustainable. On other occasions, the politicians are supportive, such as the passing of bylaws to bar unlined pit latrines in Kampala city.

Socio-technical landscape pressures influencing groundwater contamination by OSS in the Bwaise informal settlement include influences from international and regional collaborative networks, industrialization, natural phenomena, and supportive governance. Several development partners and civil society provide support for pro-poor interventions for improved water and sanitation services targeting informal settlements. The Bwaise informal settlement was among the settlements to benefit from the pro-poor interventions by the NWSC, KCCA, and civil society actors. However, increased industrialization in Kampala has led to increased urbanization, which has led to increased populations living in Bwaise and other informal settlements, greatly outstripping the existing infrastructure. Natural pressures arising from climate change effects have also influenced groundwater contamination by OSS in Bwaise, transported through increased flooding. A resident of Bwaise observed the following:

"When it rains, running water (flood water) gathers garbage from a higher altitude and brings it down to lower areas ... other people open up their toilets during the rainy season where they allow running water by rain to take all the feces into the groundwater."

The niche factors influencing the innovation of groundwater protection for conjunctive utilization along the municipal water supply are also presented in Table 3. The Bwaise community expressed support towards the implementation of a WSP for groundwater protection from OSS contamination hazards. There is increased community awareness on groundwater contamination from OSS, although limited to microbial contamination. Remarks from one of the community resident participants alluded to the level of awareness:

“... one of my kids took (drunk) the water from the spring (not boiled), and that night we had to rush to the hospital with serious diarrhea."

Due to increased awareness, community members are willing to contribute to and participate in groundwater protection initiatives, as exemplified in the participation in the 
arena process. This improves ownership of interventions and leads to solutions that are affordable to maintain by the community, thereby increasing sustainability. The community support for the protection and use of the groundwater is also attributed to the cultural and historical value of the groundwater resources, which the communities have relied upon traditionally before the evolvement of the municipal water supply. The communities expressed the willingness to sustainably protect their groundwater resources through the establishment of a community group for sanitation and water (The Bwaise Sanitation Development Group).

\section{Discussion}

This research aimed to contribute to the development of a socio-institutional assessment framework for groundwater contamination hazards through demonstrating the recent extent of groundwater contamination by OSS in the Bwaise informal settlement and exploring the socio-institutional drivers of the contamination. The prevalence of E. coli in water matrices has been widely accepted as an indicator of fecal contamination from warm-blooded animals $[2,3,54]$. The land-use within the immediate catchment is predominantly low-cost residential, relying on OSS $[10,11,44]$. The study showed that the majority of the sampled sources tested positive for E. coli, demonstrating contamination by fecal matter. The high nitrate and chloride concentrations registered in a non-agricultural influenced catchment are also a demonstration of contamination by OSS. A positive correlation between nitrate and chloride concentrations demonstrates that both are released from a common source $[2,3,10]$. A nitrate to chloride ration in the range of $1-8$ is also a commonly used indication of groundwater contamination by fecal matter [2,11]. The high levels of ammonia also indicate recent contamination by organic matter [54]. Therefore, the results from this study highly suggest that the groundwater is contaminated by domestic sources, mainly OSS. These findings are consistent with previous studies in Bwaise and the surrounding areas, which attributed the poor water quality to contamination by OSS practices $[3,10,11,46]$. Thus, the challenge of groundwater contamination by OSS practices remains prevalent in the study area. The microbial and hydro-chemical characteristics of groundwater in the study are also consistent with the findings on groundwater contamination in other peri-urban areas in SSA influenced by OSS [5,8,9]. The findings from the interviews and transition arenas attest to the periodic discharge of OSS contents during rainfall events, which increase the level of microbial contamination during the wet season. This may also explain why BH11, located in the low-lying area, registered the highest level of E. coli contamination. Kulabako et al. [11] also showed higher bacteriological, nitrate, and chloride contamination levels in the study area during the wet season. Nsubuga and Rautenbach [56] reported that climate change effects have resulted in variations in rainfall patterns in Uganda, with a slight increase in rainfall within the L. Victoria basin, where the study area lies (Figure 2).

From the study findings (Table 3), we abstract six socio-institutional drivers of the observed groundwater contamination in Bwaise, namely, "Land-use management" (L), "user attributes" (U), "governance" (G), "infrastructure management" (I), "valuation of groundwater services" (V), and the "operating environment" (E), or the "LUGIVE" factors. The qualitative indicators for each of the drivers (Table 3) present the variables for measurement of the drivers. The interrelation of the drivers and indicators are shown in Figure 4. Despite the high levels of contamination from OSS observed in Bwaise, the community still highly valued the groundwater source for occasional conjunctive utilization with the municipal water supply. Wang et al. [28] proposed that community valuation of the water resource greatly influences the level of managing the risk; thus, it should be integrated into hazard analysis. In addition, this study proposes that user attributes, including perceptions on groundwater use, as well as socio-cultural and religious beliefs, also may affect OSS performance, thus contaminating the groundwater. Omar et al. [57] emphasized the influence of cultural factors in a water utility performance in the implementation of WSPs. Water and sanitation services governance and infrastructure management are also noted as 
key drivers of groundwater contamination by OSS in the case study. Several studies have explored policy, regulation, and management aspects of improving OSS in urban areas in developing countries $[33,34,39]$. Thus, governance and infrastructure management, usually termed as "sanitation service chain management", deserve attention in the analysis of OSS hazards to groundwater in informal settlements, which are included in the "LUGIVE" assessment framework.

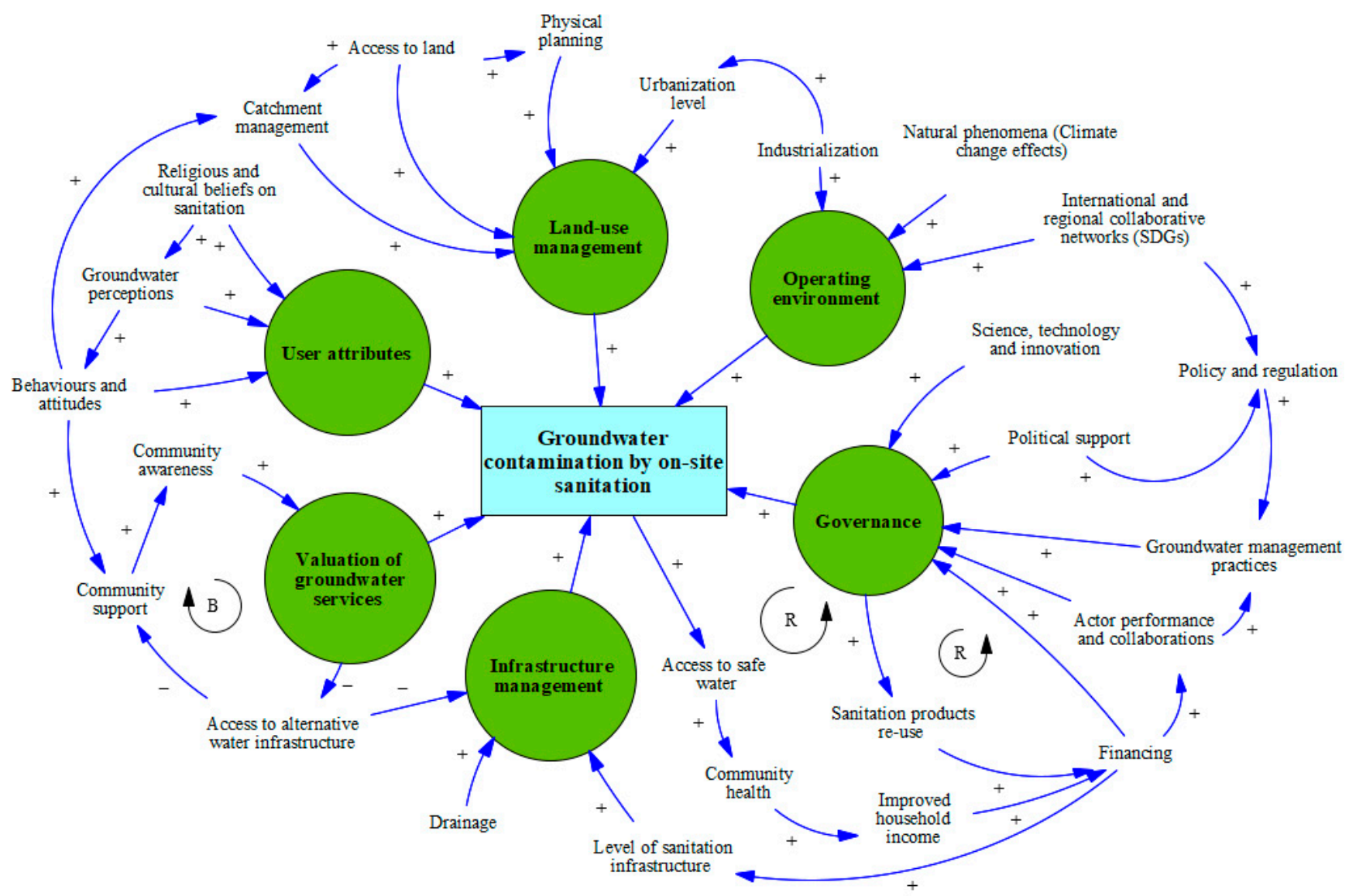

Figure 4. A causal loop diagram representing socio-institutional drivers of groundwater contamination by on-site sanitation in the Bwaise informal settlement, Kampala.

Previous studies have made an effort to integrate anthropogenic factors into groundwater contamination risk assessment, although to a limited extent of analysis. Ouedraogo et al. [17] differentiated land-use factors on the basis of urban, cropland, grassland, trees, and bare land. With this classification, all urban areas would bear a similar influence on the risk assessment, despite differences in socio-institutional dynamics, which vary across different urban areas. Saidi et al. [20] improved the analysis by differentiating between the different levels of urbanization and socio-economic status in order to have different levels of impact on the risk, but the analysis was also limited on taking into consideration the socioinstitutional characteristics of the different urban areas. Singh et al. [58] also took into consideration the anthropogenic factors, but only based on satellite imagery of urban areas to differentiate the impact level, which does not reflect the socio-institutional dynamics within the urban areas. This case study differentiates between the land-use practices and the socio-institutional characteristics of the urban areas.

The "LUGIVE" assessment framework provides an empirically derived comprehensive assessment of socio-institutional factors that influence groundwater contamination by OSS, which would lead to an improved contamination hazard assessment. Groundwater contamination risk assessment is a function of both hazard and vulnerability assessments [18-20]. Therefore, integrating "LUGIVE" factors as part of the hazard assessment 
would offer an improved socio-hydrogeological risk assessment framework. Such a framework can enable the community and policymakers to assess socio-institutional levers of control to mitigate the risk of groundwater contamination by OSS in informal settlements, since hydrogeological measures like groundwater remediation are not plausible in such informal settlements [4].

Figure 4 presents a systemic approach to analayzing the "LUGIVE" assessment framework through a CLD, which enables analysis of the influence of different socio-institutional actions on the extent of groundwater contamination. In this study, we observe a reinforcing feedback loop, which shows that reducing groundwater contamination by OSS can contribute to improved access to safe water, which leads to improved health of community members, and thus, economic productivity, which in turn leads to increased financing for improved OSS. Another positive feedback loop relates to the increased re-use of sanitation products, which may contribute to increased financing of sanitation activities. On the other hand, a balancing loop is observed, which indicates a low valuation of groundwater services when alternative sources of water supply increase. Risk management measures, therefore, can be designed to promote the positive feedback loops, which result in overall system improvement, while designing measures to dampen the effects of balancing loops. Kotir et al. [52] demonstrated a similar approach to developing solutions to water resources management challenges in the Volta River basin, while Sterman [53] attests to the growing importance of system dynamics in analyzing complex sustainability problems.

However, this study only analyzed qualitative information from a typical case of Bwaise and its surroundings in Kampala city (Uganda). Informal settlements are contamination "hot-spots" in the entire groundwater catchment; thus, they represent the highest sources of groundwater contamination by OSS. The extrapolation of case study findings is always challenging, more so for qualitative studies; however, informal settlements in SSA face somewhat similar social-economic challenges, as commonly reported across SSA $[3,8,39,45]$. Multiple case studies are recommended for future studies to underscore the differences in various country and regional water and sanitation service regimes. An increased geographical scope and a wider range of participants would also provide quantitative information, which would also provide the basis for determining the relative importance of each of the drivers, thus providing a rating and weighting criterion.

\section{Conclusions}

This study contributed to the development of a socio-institutional assessment framework for groundwater contamination hazards in informal settlements through a sociotechnical approach. We demonstrated the recent extent of groundwater contamination by OSS in a Bwaise informal settlement through a snapshot survey of microbial and hydrochemical indicator parameters and then explored the socio-institutional drivers of the contamination. The recent extent of groundwater contamination by OSS was observed to be high, demonstrated by a high prevalence of $E$. coli bacteria in the majority of the sources sampled and moderately elevated concentrations of nitrates, ammonia, and chlorides. The nitrate concentrations at four of the sampled sources exceeded the WHO guideline value for nitrates (50 mg/L) and the Uganda standard value for ammonia $(0.5 \mathrm{mg} / \mathrm{L})$. The nitrate concentrations showed a strong positive correlation with chloride concentrations $(r=0.908$; $p<0.01$ ), indicating a common source, deduced as the influence from OSS. Despite the high fecal contamination level, the community living in the study area expressed a high valuation of the groundwater sources as alternative sources to the municipal water supply, which was, in most cases, inadequate. The socio-institutional drivers of groundwater contamination by OSS in Bwaise were deduced from the key informant interviews and transition arenas with the acronym "LUGIVE" (land-use management, user attributes, governance, infrastructure management, groundwater valuation (niche), and the operating environment). The qualitative indicators for the measurement of each of the drivers were also deduced and presented in a causal loop diagram, exploring the interlinkages between the variables. While the intrinsic vulnerability and pollutant factors are static, the socio- 
institutional factors are dynamic and within the control of the actors at varying levels. This enables the analysis of different socio-institutional control levers that can be explored for sustainable approaches towards managing the risk of groundwater contamination by OSS in informal settlements in SSA. Analyzing the different reinforcing and balancing loops in the framework helps the community to identify and prioritize the socio-institutional interventions that can have a sustainable impact in reducing the contamination risk. However, the findings of this study are based on a single case study, with limited generalizability; thus, we recommend validating these research findings in multiple case studies depicting different socio-hydrogeological settings.

Supplementary Materials: The following are available online at https://www.mdpi.com/article/ 10.3390/w13162153/s1, (A) Table S1: Risk of contamination of the sampled sources, Figure S1: Lithological profile at the sampled locations in Bwaise and Table S2: Microbial and hydro-chemical measurements per sampling location in Bwaise; (B) Interview schedule and transition arena guide; (C) Table S3: Data codes, categories, and themes.

Author Contributions: Conceptualization, F.R.B.T., R.N.K., F.K. and P.M.N.; methodology, F.R.B.T.; software, F.R.B.T. and A.M.; validation, P.M.N. and G.S.; formal analysis, F.R.B.T.; investigation, R.N.K., F.R.B.T., G.S., P.M.N., J.K., F.K. and J.I.; resources, J.W.F., R.N.K. and P.M.N.; data curation, F.R.B.T.; writing —original draft preparation, F.R.B.T.; writing—review and editing, F.R.B.T. and P.M.N.; visualization, A.M.; supervision, F.K., J.W.F., P.M.N. and R.N.K.; project administration, J.W.F., P.M.N. and R.N.K.; funding acquisition, J.W.F. and R.N.K. All authors have read and agreed to the published version of the manuscript.

Funding: This research was funded by the UK Department for International Development (DFID), the Economic and Social Research Council (ESRC), and the Natural and Environment Research Council (NERC) under the UPGro Program, grant number NE/M008045/1.

Institutional Review Board Statement: The study was conducted in accordance with the Uganda National Council for Science and Technology (registration number SS482ES), and the protocol was approved by the Ethics Committee of Makerere University School of Social Sciences (study protocol number MAKSS REC 01.20.377).

Informed Consent Statement: Informed consent was obtained from all subjects involved in the study.

Data Availability Statement: The raw data can be obtained from the corresponding author.

Acknowledgments: The authors are grateful to the study participants and research assistants. The contribution of the reviewers and the academic editors is also acknowledged.

Conflicts of Interest: The authors declare no conflict of interest.

Appendix A

Table A1. Description of Key Acronyms Used in the Study.

\begin{tabular}{|c|c|}
\hline Acronym & Description \\
\hline DRASTIC & $\begin{array}{c}\text { Depth to groundwater, net recharge to the aquifer, aquifer media, soil media, topography, the impact of the vadose zone, and } \\
\text { conductivity of the aquifer }\end{array}$ \\
\hline GOD & Groundwater occurrence including recharge, overlying lithology, and depth to groundwater \\
\hline HYDRUS & $\begin{array}{c}\text { A dual-porosity model for simulating water, heat, and solute movement in the unsaturated zone between the soil surface and } \\
\text { the groundwater table }\end{array}$ \\
\hline IWRM & Integrated water resources management \\
\hline LUGIVE & $\begin{array}{c}\text { Land-use management, user attributes, governance, infrastructure management, groundwater valuation (niche), and the } \\
\text { operating environment (this paper) }\end{array}$ \\
\hline MLP & Multi-level perspective \\
\hline MIKE SHE & $\begin{array}{l}\text { A physically based, integrated water resources model that simulates both surface and subsurface water dynamics, including } \\
\text { interception, evapotranspiration, overland flow, channel flow, unsaturated flow, and saturated zone flow. }\end{array}$ \\
\hline MODFLOW & Three-Dimension Finite-Difference Groundwater Flow Model (US Geological Survey) \\
\hline OSS & On-site sanitation systems (including pit latrines and septic tanks) \\
\hline SDG & Sustainable Development Goals (United Nations) \\
\hline SINTACS & $\begin{array}{r}\text { Depth to groundwater, recharge action, attenuation potential of the vadose zone, attenuation potential of the soil, hydrogeologic } \\
\text { characteristics of the aquifer, hydraulic conductivity, and topographic slope. }\end{array}$ \\
\hline WSP & Water safety plan \\
\hline
\end{tabular}




\section{References}

1. Gleeson, T.; Wada, Y.; Bierkens, M.F.P.; Van Beek, L.P.H. Water balance of global aquifers revealed by groundwater footprint. Nature 2012, 488, 197-200. [CrossRef] [PubMed]

2. ARGOSS. Guidelines for Assessing the Risk to Groundwater from On-Site Sanitation; ARGOSS: London, UK, 2001.

3. Lutterodt, G.; Foppen, J.W.; Uhlenbrook, S. Escherichia coli strains harvested from springs in Kampala, Uganda: Cell characterization and transport in saturated porous media. Hydrol. Process. 2014, 28, 1973-1988. [CrossRef]

4. K'oreje, K.O.; Okoth, M.; Van Langenhove, H.; Demeestere, K. Occurrence and treatment of contaminants of emerging concern in the African aquatic environment: Literature review and a look ahead. J. Environ. Manag. 2020, 254, 109752. [CrossRef] [PubMed]

5. Lapworth, D.J.; Nkhuwa, D.C.W.; Okotto-Okotto, J.; Pedley, S.; Stuart, M.E.; Tijani, M.N.; Wright, J. Urban groundwater quality in sub-Saharan Africa: Current status and implications for water security and public health. Hydrogeol. J. 2017, 25, 1093-1116. [CrossRef]

6. United Nations. Transforming Our World: The 2030 Agenda for Sustainable Development; United Nations: New York, NY, USA, 2015. Available online: https://sdgs.un.org/publications/transforming-our-world-2030-agenda-sustainable-development-17981 (accessed on 26 June 2021).

7. Adelana, S.M.A. Monitoring groundwater resources in Sub-Saharan Africa: Issues and challenges. In Groundwater and Climate in Africa, Proceedings of the Kampala Conference, Kampala, Uganda, 23-25 June 2008; IAHS Press: Wallingford, UK, 2009 ; pp. $103-113$.

8. Aboagye, D.; Zume, J.T. Assessing groundwater quality in peri-urban localities of Kumasi, Ghana. Afr. Geogr. Rev. 2019, 38, 390-405. [CrossRef]

9. Anim-Gyampo, M.; Anornu, G.K.; Agodzo, S.K.; Appiah-Adjei, E.K. Groundwater risk assessment of shallow aquifers within the Atankwidi Basin of Northeastern Ghana. Earth Syst. Environ. 2019, 3, 59-72. [CrossRef]

10. Nyenje, P.M.; Foppen, J.W.; Kulabako, R.; Muwanga, A.; Uhlenbrook, S. Nutrient pollution in shallow aquifers underlying pit latrines and domestic solid waste dumps in urban informal settlements. J. Environ. Manag. 2013, 122, 15-24. [CrossRef]

11. Kulabako, N.R.; Nalubega, M.; Thunvik, R. Study of the impact of land use and hydrogeological settings on the shallow groundwater quality in a peri-urban area of Kampala, Uganda. Sci. Total Environ. 2007, 381, 180-199. [CrossRef] [PubMed]

12. UN-Habitat. Slum Almanac 2015-2016: Tracking Improvement in the Lives of Slum Dwellers; UN-Habitat: Nairobi, Kenya, 2016.

13. Nixdorf, E.; Sun, Y.; Su, J.; Wang, Q.; Wang, T.; Kolditz, O.; Xi, B. Groundwater risk sources identification and risk reduction management in the Song-Liao-River-Basin. In Chinese Water Systems, Terrestrial Environmental Sciences; Song, Y., Ed.; Springer: Berlin/Heidelberg, Germany, 2018. [CrossRef]

14. Werz, H.; Hötzl, H. Groundwater risk intensity mapping in semi-arid regions using optical remote sensing data as an additional tool. Hydrogeol. J. 2007, 15, 1031-1049. [CrossRef]

15. Aller, L.; Bennett, T.; Lehr, J.H.; Petty, R.J.; Hackett, G. DRASTIC: A Standardized System for Evaluating Groundwater Potential Using Hydrogeologic Settings; EPA/600/2-85/018; U.S. Environmental Protection Agency: Washington, DC, USA, 1987.

16. Boulabeiz, M.; Klebingat, S.; Agaguenia, S. A GIS-based GOD model and hazard index analysis: The quaternary coastal Collo Aquifer (NE-Algeria). Groundwater 2019, 57, 166-176. [CrossRef] [PubMed]

17. Ouedraogo, I.; Defourny, P.; Vanclooster, M. Mapping the groundwater vulnerability for pollution at the pan African scale. Sci. Total Environ. 2016, 544, 939-953. [CrossRef]

18. Wang, J.; He, J.; Chen, H. Assessment of groundwater contamination risk using hazard quantification, a modified DRASTIC model and groundwater value, Beijing Plain, China. Sci. Total Environ. 2012, 432, 216-226. [CrossRef] [PubMed]

19. Barbulescu, A. Assessing groundwater vulnerability: DRASTIC and DRASTIC-Like methods: A review. Water 2020, $12,1356$. [CrossRef]

20. Saidi, S.; Bouri, S.; Ben Dhia, H.; Anselme, B. Assessment of groundwater risk using intrinsic vulnerability and hazard mapping: Application to Souassi aquifer, Tunisian Sahel. Agric. Water Manag. 2011, 98, 1671-1682. [CrossRef]

21. Machiwal, D.; Jha, M.K.; Singh, V.P.; Mohan, C. Assessment and mapping of groundwater vulnerability to pollution: Current status and challenges. Earth Sci. Rev. 2018, 185, 901-927. [CrossRef]

22. Re, V.; Sacchi, E.; Kammoun, S.; Tringali, C.; Trabelsi, R.; Zouari, K.; Daniele, S. Integrated socio-hydrogeological approach to tackle nitrate contamination in groundwater resources. The case of Grombalia Basin (Tunisia). Sci. Total Environ. 2017, 593-594, 664-676. [CrossRef] [PubMed]

23. Tringali, C.; Re, V.; Siciliano, G.; Chkir, N.; Tuci, C.; Zouari, K. Insights and participatory actions driven by a socio-hydrogeological approach for groundwater management: The Grombalia Basin case study (Tunisia). Hydrogeol. J. 2017, 25, 1241-1255. [CrossRef]

24. Troy, T.J.; Konar, M.; Srinivasan, V.; Thompson, S. Moving sociohydrology forward: A synthesis across studies. Hydrol. Earth Syst. Sci. 2015, 19, 3667-3679. [CrossRef]

25. WHO. Water Safety Plans: Managing Drinking-Water Quality from Catchment to Consumer; World Health Organization Press: Geneva, Switzerland, 2015.

26. Rickert, B.; Schmoll, O.; Rinehold, A.; Barrenberg, E. Water Safety Plan: A Field Guide to Improving Drinking-Water Safety in Small Communities; World Health Organization Press: Geneva, Switzerland, 2014.

27. Global Water Partnership. Integrated Water Resources Management, Technical Advisory Committee Background Papers (No. 4); Global Water Partnership: Stockholm, Sweden, 2000. Available online: https://www.gwp.org/globalassets/global/toolbox/ publications/background-papers/ 04-integrated-water-resources-management-2000-english.pdf (accessed on 4 August 2021). 
28. Biswas, A.K. Integrated Water Resources Management: Is it working? Int. J. Water Resour. Dev. 2008, 24, 5-22. [CrossRef]

29. Foster, S.S.D.; Ait-Kadi, M. Integrated Water Resources Management (IWRM): How does groundwater fit in? Hydrogeol. J. 2012, 20,415-418. [CrossRef]

30. Loorbach, D. Transition management for sustainable development: A prescriptive, complexity-based governance framework. Governance 2010, 23, 161-183. [CrossRef]

31. Rauschmayer, F.; Bauler, T.; Schäpke, N. Towards a thick understanding of sustainability transitions—Linking transition management, capabilities and social practices. Ecol. Econ. 2015, 109, 211-221. [CrossRef]

32. Roorda, C.; Wittmayer, J.; Henneman, P.; van Steenbergen, F.; Frantzeskaki, N.; Loorbach, D. Transition Management in the Urban Context: Guidance Manual; Dutch Research Institute for Transitions, Erasmus University: Rotterdam, The Netherlands, 2014.

33. Twinomucunguzi, F.R.B.; Nyenje, P.M.; Kulabako, R.N.; Semiyaga, S.; Foppen, J.W.; Kansiime, F. Reducing groundwater contamination from on-site sanitation in peri-urban Sub-Saharan Africa: Reviewing transition management attributes towards implementation of water safety plans. Sustainability 2020, 12, 4210. [CrossRef]

34. Silvestri, G.; Wittmayer, J.M.; Schipper, K.; Kulabako, R.; Oduro-Kwarteng, S.; Nyenje, P.M.; Komakech, H.C.; van Raak, R. Transition management for improving the sustainability of WASH services in informal settlements in Sub-Saharan Africa-An exploration. Sustainability 2018, 10, 4052. [CrossRef]

35. Kabote, J.L.; Mosha, A.K.P.R. Effectiveness of groundwater governance structures and institutions in Tanzania. Appl. Water Sci. 2018, 8, 1-14. [CrossRef]

36. Daré, W.; Venot, J.P.; Le Page, C.; Aduna, A. Problemshed or watershed? Participatory modeling towards IWRM in North Ghana. Water 2018, 10, 721. [CrossRef]

37. Pahl-Wostl, C.; Holtz, G.; Kastens, B.; Knieper, C. Analyzing complex water governance regimes: The Management and transition framework. Environ. Sci. Policy 2010, 13, 571-581. [CrossRef]

38. Geels, F.W. Technological transitions as evolutionary reconfiguration processes: A multi-level perspective and a case-study. Res. Policy 2002, 31, 1257-1274. [CrossRef]

39. Van Welie, M.J.; Truffer, B.; Gebauer, H. Innovation challenges of utilities in informal settlements: Combining a capabilities and regime perspective. Environ. Innov. Soc. Transit. 2019, 33, 84-101. [CrossRef]

40. Yin, R.K. The case study as a serious research strategy. Sci. Commun. 1981, 3, 97-114. [CrossRef]

41. Eisenhardt, K.M.; Graebner, M.E. Theory building from cases: Opportunities and challenges. Acad. Manag. J. 2007, 50, 25-32. [CrossRef]

42. UBOS. The National Population and Housing Census 2014; Uganda Bureau of Statistics: Kampala, Uganda, 2014.

43. Geological Survey of Finland (GTK). Geology and Geodynamic Development of Uganda with Explanation of the 1:1,000,000 Scale Geological Map (Special Paper 55); GTK: Espoo, Finland, 2014.

44. Twinomucunguzi, F.R.B.; Nyenje, P.M.; Kulabako, R.N.; Semiyaga, S.; Foppen, J.W.; Kansiime, F. Emerging organic contaminants in shallow groundwater underlying two contrasting peri-urban areas in Uganda. Environ. Monit. Assess. 2021, 193, 228. [CrossRef] [PubMed]

45. Van Dijk, M.P. Benchmarking sanitation for the poor has to take the real sanitary problems in the informal settlements of Kampala as the point of departure. Int. J. Water 2016, 10, 175-191. [CrossRef]

46. Katukiza, A.Y.; Ronteltap, M.; Niwagaba, C.B.; Foppen, J.W.A.; Kansiime, F.; Lens, P.N.L. Sustainable sanitation technology options for urban informal settlements. Biotechnol. Adv. 2012, 30, 964-978. [CrossRef]

47. WHO. Guidelines for Drinking-Water Quality: Surveillance and Control of Community Supplies, 2nd ed.; World Health Organization Press: Geneva, Switzerland, 1997.

48. Mushi, D.; Byamukama, D.; Kirschner, A.K.T.; Mach, R.L.; Brunner, K.; Farnleitner, A.H. Sanitary inspection of wells using risk-of-contamination scoring indicates a high predictive ability for bacterial faecal pollution in the peri-urban tropical lowlands of Dar es Salaam, Tanzania. J. Water Health 2012, 10, 236-243. [CrossRef]

49. Guest, G.; Brunce, A.; Johnson, L. How many interviews are enough?: An experiment with data saturation and variability. Field Methods 2006, 18, 59. [CrossRef]

50. Braun, V.; Clarke, V. Using thematic analysis in psychology. Qual. Res. Psychol. 2006, 3, 77-101. [CrossRef]

51. Sousa, D. Validation in qualitative research: General aspects and specificities of the descriptive phenomenological method. Qual. Res. Psychol. 2014, 11, 211-227. [CrossRef]

52. Kotir, J.H.; Smith, C.; Brown, G.; Marshall, N.; Johnstone, R. A system dynamics simulation model for sustainable water resources management and agricultural development in the Volta River. Sci. Total Environ. 2016, 573, 444-457. [CrossRef]

53. Sterman, J.D. System dynamics at sixty: The path forward. Syst. Dyn. Rev. 2018, 34, 5-47. [CrossRef]

54. WHO. Guidelines for Drinking-Water Quality, 4th ed.; World Health Organization Press: Geneva, Switzerland, 2011.

55. UNBS. Uganda Standard (US EAS 12: 2014): Potable Water-Specification 2014; Uganda National Bureau of Standards (UNBS): Kampala, Uganda, 2014.

56. Nsubuga, F.W.; Rautenbach, H. Climate change and variability: A review of what is known and ought to be known for Uganda. Int. J. Clim. Chang. Strateg. Manag. 2018, 10, 752-771. [CrossRef] 
57. Omar, Y.Y.; Parker, A.; Smith, J.A.; Pollard, S.J.T. Risk management for drinking water safety in low and middle income countriesCultural influences on Water Safety Plan (WSP) implementation in urban water utilities. Sci. Total Environ. 2017, 576, 895-906. [CrossRef] [PubMed]

58. Singh, A.; Srivastav, S.K.; Kumar, S.; Chakrapani, J.G. A modified-DRASTIC model (DRASTICA) for assessment of groundwater vulnerability to pollution in an urbanized environment in Lucknow. India. Environ. Earth Sci. 2015, 74, 5475-5490. [CrossRef] 